\title{
RISK FACTORS ASSOCIATED WITH HYPERTENSION AMONG ADULTS RESIDING IN AN URBAN AREA OF KERALA- A CROSS-SECTIONAL STUDY
}

\author{
Prabhakumari Chellammaㄹ, Jayasree Chandrasekharan Nair², Athira Thekke Kottarath ${ }^{3}$, Ankitha Saleem ${ }^{4}$, Asha Thulaseedharan Jaya ${ }^{5}$, \\ Aleesha Thaj6
}

1 Professor and HOD, Department of Community Medicine, Travancore Medical College, Kollam.

2Professor, Department of Community Medicine, Travancore Medical College, Kollam.

${ }^{3}$ House Surgeon, Department of Community Medicine, Travancore Medical College, Kollam.

${ }^{4}$ House Surgeon, Department of Community Medicine, Travancore Medical College, Kollam.

${ }^{5}$ House Surgeon, Department of Community Medicine, Travancore Medical College, Kollam.

${ }^{6}$ House Surgeon, Department of Community Medicine, Travancore Medical College, Kollam.

\begin{abstract}
BACKGROUND
ABSTRACT

Kerala is an Indian state, which is advanced with respect to various health indicators like infant mortality rate, maternal mortality rate, immunisation coverage, family planning acceptance etc., also social determinants like literacy, transport facilities, health awareness etc. But the state is facing the problem of a sharp increase in certain communicable diseases, especially the vector-borne diseases. The situation with regard to Non-Communicable Diseases too is a serious one in the state. Hypertension, which is well recognised as a cause for prolonged morbidity and decrease in quality of life has assumed the proportions of an important public health problem here. By this study we attempted to find out the prevalence of hypertension among adults residing in Kollam Municipal Corporation area. An exploration into the factors, which are associated with hypertension has also been done. The findings can help in identifying the pertinent aspects of high blood pressure among urban population. This information can be used in planning and implementing suitable steps in controlling hypertension in urban population.
\end{abstract}

The objectives of this study are-

1. To find out the prevalence of hypertension among adults residing in an urban area of Kerala.

2. To determine the factors associated with hypertension in the above population.

\section{MATERIALS AND METHODS}

A cross-sectional study was conducted during the months of February and March of 2017. The study area included 4 wards in the Kollam Municipal Corporation area. The study subjects included 300 individuals above 18 years of age, residing in the study area.

\section{RESULTS}

The prevalence of hypertension was found to be $40 \%$ in the study area; $27 \%$ were identified as pre-hypertensives. Higher age and better educational status have significant association with hypertension ( $\mathrm{p}$ value $<.05$ ). Also stress, comorbidities, increased BMI and waist: hip ratio, positive family history and alcohol intake were found to be significantly associated with high blood pressure $(\mathrm{p}<0.05)$.

\section{CONCLUSION}

The prevalence of pre-hypertension is also high. Programmes focusing on weight reduction, stress relief, alcohol intake etc. and proper management of comorbidities can reduce the prevalence of hypertension.

\section{KEYWORDS}

Urban population, Hypertension, Prevalence, Risk Factors.

HOW TO CITE THIS ARTICLE: Chellamma P, Nair JC, Kottarath AT, et al. Risk factors associated with hypertension among adults residing in an urban area of Kerala- a cross-sectional study. J. Evolution Med. Dent. Sci. 2017;6(90):6316-6321, DOI: $10.14260 /$ jemds/2017/1374

\section{BACKGROUND}

Hypertension is a chronic condition of concern due to its role in the causation of coronary heart disease, stroke and other vascular complications. It is the commonest cardiovascular disorder posing a major public health challenge to population in socio-economic and epidemiological transition. It is one of

'Financial or Other Competing Interest': None.

Submission 13-10-2017, Peer Review 06-11-2017,

Acceptance 13-11-2017, Published 20-11-2017.

Corresponding Author:

Dr. Jayasree Chandrasekharan Nair,

"Shree Nandanam," VARA-746-A,

Near HDFC Bank, Vattiyoorkavu P.O,

Thiruvananthapuram, Kerala.

E-mail: jayasree_cs@yahoo.com

DOI: $10.14260 /$ jemds $/ 2017 / 1374$

\section{(c) (i) $(5)$}

the major risk factors for cardiovascular mortality, which accounts for 20 - 25 percent of all deaths.[1] The first hypertension prevalence study in India was done by Chopra et al in 1942 with continuation thereafter. Literature search and findings of many of the studies found a regular increase in the prevalence of hypertension. In India with a population estimation of 1.1 billion, the prevalence of HTN has been estimated to be $3 \%$ to $34.5 \%$ in males and $5.8 \%$ to $33.5 \%$ in females. By the end of 2025, the projected prevalence of HTN in Indian men and women are $22.9 \%$ and $23.6 \% .{ }^{[2]}$

The prevalence of hypertension in the last six decades has increased from $2 \%$ to $25 \%$ among urban residents and from $2 \%$ to $15 \%$ among the rural residents in India. Recent studies from India have shown the prevalence of HTN to be $25 \%$ in urban and $10 \%$ in rural adults in India.(2) All over India, the urban population shows a steep increase in the prevalence of 
hypertension.(3) The prevalence of hypertension among women in Thiruvananthapuram city was found to be $30.6 \%$,(4) very high prevalence of $52 \%$ was reported in a sample of elderly population in Thiruvananthapuram.(5)

As far as Kerala is concerned, most of the state does not show a sharp demarcation between the urban and rural areas. The demography and social organisation are similar in almost all areas in Kerala. Still the number of health care institutions and accessibility to health care is marginally better in urban areas. So, we attempted to find out the prevalence of hypertension in adults who are residents of Kollam Municipal Corporation.

Studies done in both rural and urban settings have found out that the prevalence of comorbidities like diabetes mellitus, hypercholesterolemia are also high. Moreover, complications due to hypertension were also high in such cases.(6)

An attempt at control of hypertension is possible only if an in-depth study is done regarding the various risk factors prevalent in the area. Several workers have identified factors like obesity, sedentary lifestyle, hypercholesterolemia, high salt intake, smoking, alcoholism, intake of certain drugs, mental stress etc. to be associated with hypertension. An understanding of how these factors operate at the individual level and community level is crucial to formulating and implementing robust and effective prevention and control programmes.(7)

Health policies are formulated by the state based on this information. Risk factor studies in hypertension by various investigators have proved that any control programme will essentially need multisectoral efforts to bring about a positive outcome.(8)

\section{MATERIALS AND METHODS}

\section{Study Design}

Cross-Sectional Study.

\section{Study Sample}

Adults above 18 years who are residents of the study area for at least the past 1 year.

\section{Study Period}

February 4th 2017 to April 3rd 2017

\section{Study Setting}

The study was conducted in an urban area in Kollam district in Kerala. Kollam Municipal Corporation has 55 wards. Of these, 12 wards fall within the field practice area of the Community Medicine Department of Travancore Medical College. The population of each of these wards comes to about 7000.(9) The general characteristics of the population inhabiting these areas are more or less similar. The study was conducted in 4 wards randomly selected from these 12 urban wards.

\section{Sample Size}

A pilot study was conducted in the selected area by the investigators. It was found out that the overall prevalence of hypertension in adults came to $25 \%$. So $25 \%$ was taken as the prevalence and the sample size was calculated. Applying the formula $4 \mathrm{pq} / \mathrm{d} 2$, the sample size is $4 \times 25 \times 75 / 5 \times 5=300$

\section{Sampling Technique}

The population in each of the 12 urban wards coming in the field practice area of Travancore Medical College comes to about 7000 . The general and demographic characteristics and infrastructure facilities of all these 12 wards is more or less homogenous. Hence, 4 wards were randomly selected out of these 12 wards. From each ward, 75 individuals were selected so that a total of 300 is got ( $75 \times 4)$. In each ward, the first house was selected randomly. Then from that house, every $5^{\text {th }}$ house was selected. All individuals residing in the house who were above 18 years of age were included in the study. This was continued till 75 individuals were got in each ward.

\section{Inclusion Criteria}

All individuals (both male and female) of age 18 years or above from the selected houses, residing in the study area for at least the past 1 year.

\section{Exclusion Criteria}

1. Seriously ill patients.

2. Known cases of secondary hypertension.

3. Persons with difficulties in communicating like mentally challenged individuals.

\section{Data Collection}

The data was collected by using a pretested structured questionnaire by interviewing the study subjects, which was done by the investigators.

Measurements of blood pressure, weight, height, waist and hip circumferences were made by the investigators using standardised mercury sphygmomanometer, beam balance, anthropometric rod and non-stretchable measuring tape respectively.

The blood pressure was measured after a resting period of 5 minutes using a calibrated mercury sphygmomanometer; 2 measurements were made at 30 minutes interval. The average of these two readings was taken.

\section{Data Entry}

Data entry was done in Microsoft Excel. Data analysis was done using SPSS. Percentages, frequencies, means, medians etc. were calculated. Significance testing was done by using Chi-square test. A p value $<0.05$ was considered significant.

Due clearance from the Institutional Ethical Committee was obtained and after taking informed consent from the study subjects the study was conducted.

\section{Objectives}

- To study the prevalence of hypertension among adults residing in an urban area in Kerala.

- To determine the risk factors of hypertension in the study population.

\section{RESULTS}

The total number of subjects studied was 300 . In our study population, most of the people were in the age group $50-64$ yrs. (33.3\%) and most of them were females (55.9\%) and majority of them were Muslims (60\%). In our current study when family income is taken into consideration, APL families tend to be of higher incidence (84\%) as compared to BPL (16\%). Most of the study population had education of 10 standard and above (69.7\%). 


\begin{tabular}{|c|c|c|c|}
\hline Socio-Demographic Profile & Frequency & Total & (\%) \\
\hline $\begin{array}{c}\text { Age } \\
18-34 \text { yrs. } \\
35-49 \text { yrs. } \\
50-64 \text { yrs. } \\
65 \text { and above } \\
\end{array}$ & $\begin{array}{c}99 \\
67 \\
100 \\
34 \\
\end{array}$ & 300 & $\begin{array}{c}33 \\
22.3 \\
33.3 \\
11.3 \\
\end{array}$ \\
\hline $\begin{array}{c}\text { Gender } \\
\text { Male } \\
\text { Female } \\
\end{array}$ & $\begin{array}{l}106 \\
194\end{array}$ & 300 & $\begin{array}{l}44.1 \\
55.9\end{array}$ \\
\hline $\begin{array}{c}\text { Religion } \\
\text { Hindu } \\
\text { Muslim } \\
\text { Christian }\end{array}$ & $\begin{array}{c}98 \\
180 \\
22\end{array}$ & 300 & $\begin{array}{c}32.3 \\
60 \\
7.3\end{array}$ \\
\hline $\begin{array}{c}\text { Monthly Income of the } \\
\text { Family } \\
\text { APL } \\
\text { BPL }\end{array}$ & $\begin{array}{c}252 \\
48\end{array}$ & 300 & $\begin{array}{l}84 \\
16\end{array}$ \\
\hline $\begin{array}{c}\text { Education } \\
>=10 \text { yrs. of schooling } \\
<=10 \text { yrs. of schooling }\end{array}$ & $\begin{array}{c}209 \\
91\end{array}$ & 300 & $\begin{array}{l}69.7 \\
30.3\end{array}$ \\
\hline $\begin{array}{r}\text { Table 1. Socio-Demograp } \\
\text { Pop }\end{array}$ & $\begin{array}{l}\text { ic Charac } \\
\text { ation }\end{array}$ & of $t$ & tudy \\
\hline
\end{tabular}

A systolic blood pressure of $140 \mathrm{mmHg}$ or above and/ or a diastolic blood pressure of $90 \mathrm{mmHg}$ or above and/ or already on antihypertensive drugs was considered as hypertension.(10) Of the 300 individuals studied, 101 were known hypertensives already on treatment; 19 more individuals were newly detected to be hypertensives; so 120 hypertensives and 180 normotensives were identified. Of this 180,81 people $(27 \%)$ were identified as pre-hypertensives.

Hence, the prevalence of hypertension in the study population came to $40 \%$.

The risk factors that were considered in our study were physical activity, salt intake, comorbidities like diabetes mellitus, dyslipidaemia, death due to coronary artery disease below 40 yrs. in first-degree relatives, habits like smoking or alcoholism, family h/o of hypertension, BMI, waist-to-hip ratio. Majority were leading a sedentary life (79.3\%). Out of the total study population, only $8.3 \%$ of them were taking high salt. Majority of them take moderate amount of salt (add salt during cooking). The habit of smoking prevailed in $9 \%$. Prevalence of alcoholism was detected in 6\%; $29.3 \%$ lead a stressful life. From our data collected, $25.3 \%$ were k/c/o diabetes mellitus, $63 \%$ were $\mathrm{k} / \mathrm{c} / \mathrm{o}$ dyslipidaemia. Out of the total population we studied, $52 \%$ were having family history of hypertension and $7.3 \%$ had first-degree relatives having died of CAD before the age of 40 years.

\begin{tabular}{|c|c|c|}
\hline Risk Factors & Frequency & $\mathbf{\%}$ \\
\hline Physical Activity & & \\
Moderate and Above & 62 & 20.7 \\
Sedentary & 238 & 79.3 \\
\hline Salt Intake & 13 & \\
Low & 262 & 4.3 \\
Moderate & 25 & 8.3 \\
High & 27 & 9 \\
\hline Smoking & 18 & 6 \\
\hline Alcohol & 88 & 29.3 \\
\hline Stress & 76 & 25.3 \\
\hline Diabetes Mellitus & 63 & 21 \\
\hline Dyslipidaemia & 156 & 52 \\
\hline Family history in first-degree relative & 22 & 7.3 \\
\hline CAD history less than 40 yrs. & 107 & 35.7 \\
\hline BMI > 23 & 71 & 23.7 \\
\hline Waist-to-hip ratio among females & & \\
\hline
\end{tabular}

\begin{tabular}{|c|c|c|}
\hline$>0.8$ & & \\
\hline Waist-to-hip ratio among males $>0.9$ & 31 & 10.3 \\
\hline Total & $\mathbf{3 0 0}$ & $\mathbf{1 0 0}$ \\
\hline $\begin{array}{c}\text { Table 2. Risk Factors of Hypertension in the Study } \\
\text { Population }\end{array}$ \\
\hline
\end{tabular}

When BMI was taken into consideration, $35.7 \%$ were having a BMI > 23. Among females, $23.7 \%$ have a waist-to-hip ratio $>0.8$. Among males, $10.3 \%$ have a waist-to-ratio $>0.9$.

In order to find out the association between hypertension and the various risk factors studied, chi-square test was done.

\begin{tabular}{|c|c|c|c|c|c|}
\hline $\begin{array}{l}\text { Age } \\
\text { Group }\end{array}$ & $\begin{array}{l}\text { Hyper- } \\
\text { tensives } \\
(120)\end{array}$ & $\begin{array}{c}\text { Non- } \\
\text { Hyper- } \\
\text { tensives } \\
(180)\end{array}$ & $\begin{array}{c}\text { Tota } \\
1\end{array}$ & $\begin{array}{l}\text { Chi- } \\
\text { Square } \\
\text { value }\end{array}$ & $\begin{array}{c}P \\
\text { value }\end{array}$ \\
\hline $18-34$ & $5(4.2)$ & $94(52.2)$ & 99 & \multirow{4}{*}{15.5} & \multirow{4}{*}{0.001} \\
\hline $35-49$ & $19(15.8)$ & $48(26.6)$ & 67 & & \\
\hline $50-64$ & $68(56.6)$ & $32(17.7)$ & 100 & & \\
\hline$>65$ & $28(23.3)$ & $6(3.3)$ & 34 & & \\
\hline $\begin{array}{c}\text { Education } \\
>10 \text { yrs. of } \\
\text { schooling } \\
<\text { or }=10 \\
\text { yrs. } \\
\text { of schooling }\end{array}$ & $\begin{array}{l}56(46.6) \\
64(53.3)\end{array}$ & $\begin{array}{c}153(85] \\
27(15)\end{array}$ & $\begin{array}{c}209 \\
91\end{array}$ & 50.06 & .001 \\
\hline $\begin{array}{c}\text { Monthly } \\
\text { Income } \\
\text { APL } \\
\text { BPL } \\
\end{array}$ & $\begin{array}{l}95(79.1) \\
25(20.9)\end{array}$ & $\begin{array}{c}157(87.2) \\
23(12.7)\end{array}$ & $\begin{array}{c}252 \\
48\end{array}$ & 3.47 & .045 \\
\hline $\begin{array}{l}\text { Physical } \\
\text { Activity } \\
\text { Moderate } \\
\text { and above } \\
\text { Sedentary }\end{array}$ & $\begin{array}{l}28(23.3) \\
92(76.6)\end{array}$ & $\begin{array}{l}34(18.9) \\
146(8.1)\end{array}$ & $\begin{array}{c}62 \\
238\end{array}$ & .867 & .215 \\
\hline $\begin{array}{l}\text { Salt Intake } \\
\text { Low } \\
\text { Moderate } \\
\text { High }\end{array}$ & $\begin{array}{c}5(4.2) \\
105 \\
(87.5) \\
10(8.3) \\
\end{array}$ & $\begin{array}{c}8(4.4) \\
157(87.2) \\
15(8.3)\end{array}$ & $\begin{array}{c}13 \\
262 \\
25\end{array}$ & .013 & .993 \\
\hline $\begin{array}{l}\text { Alcohol } \\
\text { No } \\
\text { Yes }\end{array}$ & $\begin{array}{c}105 \\
(87.5) \\
15(12.5) \\
\end{array}$ & $\begin{array}{c}177(98.3) \\
3(1.7)\end{array}$ & $\begin{array}{c}282 \\
18\end{array}$ & 14.9 & 0.001 \\
\hline $\begin{array}{c}\text { Smoking } \\
\text { No } \\
\text { Yes }\end{array}$ & $\begin{array}{c}106 \\
(88.3) \\
14(11.7) \\
\end{array}$ & $\begin{array}{c}167(92.8) \\
13(72.2)\end{array}$ & $\begin{array}{c}212 \\
27\end{array}$ & 1.73 & .133 \\
\hline $\begin{array}{c}\text { Stress } \\
\text { No } \\
\text { Yes }\end{array}$ & $\begin{array}{l}71(59.2) \\
49(40.8) \\
\end{array}$ & $\begin{array}{c}141(78.3) \\
39(21.7)\end{array}$ & $\begin{array}{c}212 \\
88 \\
\end{array}$ & 12.7 & .001 \\
\hline $\begin{array}{c}\text { Diabetes } \\
\text { Mellitus } \\
\text { No } \\
\text { Yes } \\
\end{array}$ & $\begin{array}{l}66(55) \\
54(45)\end{array}$ & $\begin{array}{c}158(87.8) \\
22(12.2)\end{array}$ & $\begin{array}{c}224 \\
76\end{array}$ & 40.9 & .001 \\
\hline $\begin{array}{c}\text { Dyslipidae } \\
\text { mia } \\
\text { No } \\
\text { Yes } \\
\end{array}$ & $\begin{array}{l}73(60.8) \\
47(39.2)\end{array}$ & $\begin{array}{c}164(91.1) \\
16(8.9)\end{array}$ & $\begin{array}{c}237 \\
63\end{array}$ & 39.7 & .001 \\
\hline $\begin{array}{c}\text { Family } \\
\text { History } \\
\text { No } \\
\text { Yes } \\
\end{array}$ & $\begin{array}{l}41(34.2) \\
79(65.8)\end{array}$ & $\begin{array}{c}103(57.2) \\
77(42.8)\end{array}$ & $\begin{array}{l}114 \\
156\end{array}$ & 15.3 & .001 \\
\hline $\begin{array}{c}\text { CAD } \\
\text { No } \\
\text { Yes }\end{array}$ & $\begin{array}{c}104 \\
(86.7) \\
16(13.3) \\
\end{array}$ & $\begin{array}{c}174(96.7) \\
6(3.3)\end{array}$ & $\begin{array}{c}278 \\
22\end{array}$ & 10.59 & 0.001 \\
\hline $\begin{array}{c}\text { BMI } \\
</=23 \\
>23\end{array}$ & $\begin{array}{l}56(46.7) \\
64(53.3)\end{array}$ & $\begin{array}{c}137 \\
(71 \%) \\
43(40.2) \\
\end{array}$ & $\begin{array}{l}193 \\
107\end{array}$ & 27.2 & 0.001 \\
\hline
\end{tabular}




\begin{tabular}{|c|c|c|c|c|c|}
\hline $\begin{array}{c}\text { W/H Ratio } \\
\text { Male }<=0.9 \\
>0.9\end{array}$ & $26(55.3)$ & $49(83)$ & 75 & 6.086 & 0.013 \\
Female & $21(45.7)$ & $10(17)$ & 31 & 12.05 & 0.001 \\
$<=0.8$ & $35(48)$ & $88(72.7)$ & 123 & & \\
$>0.8$ & $38(52)$ & $33(27.3)$ & 71 & & \\
\hline \multicolumn{7}{|c|}{ Table 3. Risk Factors Associated with Hypertension } \\
\hline
\end{tabular}

From our study, we found that socio-demographic profiles like age, education have significant association with hypertension ( $p$ value <.05). There is more risk of developing hypertension as the age increases. Majority of the hypertensives were in the age group 50 - 64 yrs. Out of the 120 hypertensives, $56.6 \%$ were in that age group when compared to $17.7 \%$ of the normotensives. It shows a significant association ( $\mathrm{p}$ value $=.001)$. It is also found that education plays a significant role in development of hypertension. Among 120 hypertensives, 64 were having an educational qualification of less than 10 yrs. of schooling (53.3\%) ( $\mathrm{p}$ value <.001).

It is seen that most of the hypertensive individuals were above poverty line $(79.1 \%)$.

Excessive alcohol intake is an important risk factor for hypertension; $12.5 \%$ of the hypertensives were alcoholic compared to $1.6 \%$ of the normotensives, which is significant ( $p$ value $=0.001)$. Stress also plays an important role in developing hypertension. Among hypertensives $40.8 \%$ lead a stressful life, whereas only $21.6 \%$ of normotensives were stressed. We found that people having hypertension also have comorbidities like diabetes and dyslipidaemia. It was found to be significant that is $45 \%$ of hypertensives were diabetic, whereas among normotensives $12.2 \%$ were diabetic. Similarly, $39.9 \%$ were dyslipidaemic compared to $8.8 \%$ of normotensives.

A positive family history of hypertension was present in $65.8 \%$ of the hypertensive patients. Therefore, family history was found to be a significant risk factor for developing hypertension. In our current study, among 120 hypertensives 79 of them (50.6) were having positive family history ( $p$ value $=0.001$ ).

$16.6 \%$ of hypertensives were having first-degree relatives died due to CAD before the age of $40 \mathrm{yrs}$. compared to $3.3 \%$ of normotensives, which is statistically significant ( $p$ value .001).

From our data, it is clear that prevalence of hypertension is highest among overweight and obese individuals. Out of 120 hypertensives $53.3 \%$ were having a $\mathrm{BMI}>23$, whereas only $40.2 \%$ of the normotensives had a BMI > 23 ( $p$ value < 0.001).

The final risk factor included in our study was waist-tohip ratio. From the data collected it was seen that among males $45.7 \%$ of hypertensives were having waist-to-hip ratio high ( $>0.9$ ), whereas in case of females $52 \%$ were having high waist-to-hip ratio ( $>0.8$ ) as compared to $17 \%$ and $27.3 \%$ respectively among normotensives ( $\mathrm{p}$ value $<0.01$ ).

\section{DISCUSSION}

From the study conducted in surrounding area of Travancore Medical College and Hospital, it is seen that prevalence of hypertension is highest in the age group $50-64$ years (56.6\%) and least in individuals between 18 - 34 yrs. (4.1\%). Blood pressure rises with age in both sexes. Almost all Indian studies found increasing level of blood pressure with increasing age. Bombay executive study showed a prevalence of $40 \%$ in the age group $>/=50$ years.[11]

The peak age of HTN in a study conducted in Andhra Pradesh was 60 - 69 years and a proportionate increase with age was observed in both sexes. These findings may be due to changes in the vascular system as age advances. Many surveys, cross-sectional studies have demonstrated a positive relation between age and blood pressure in diverse, geographical and socioeconomic conditions.[12]

Regarding socioeconomic status, we found education and family income shows statistically significant association with hypertension. As the educational status increases, chance of developing hypertension decreases. Majority of the hypertensives were having less than 10 yrs. of schooling $(53.3 \%)$ and found that most of them were above poverty line (79.1\%), whereas in a study conducted on Prevalence of Hypertension and Determination of Its Risk Factors by Jugal Kishore et al in Rural Delhi concluded that education was an independent risk factor of hypertension.[13]

Excessive alcohol intake is an important risk factor for hypertension; $12.5 \%$ of the hypertensives were alcoholic compared to $1.6 \%$ of the normotensives. Similarly, in a study conducted by Manoj Kumar Singh Singamsetty et al in a rural community of Nellore, Andhra Pradesh, India linear trend of association was seen with tobacco and alcohol use, more than the cut-off value ( $\mathrm{p}$ value $<0.005$ ).[14]

The present study shows stress can cause raised blood pressure and lead to hypertension. Among hypertensives $40.8 \%$ lead a stressful life, whereas only $21.6 \%$ of normotensives were stressed. Several studies have suggested that chronic exposure to stress may have an influence on increased blood pressure. One such similar study conducted in Rio de Janeiro suggest the relevance of control of psychological stress to the non-therapeutic management of high blood pressure. Results showed individuals who had stronger responses to stressor task were $21 \%$ more likely to develop blood pressure increase when compared to those with less strong response (OR: 1.21; 95\% CL: $1.14-1.28$; $\mathrm{p}<0.001) .[15]$

Regarding coexisting diseases, most of the hypertensives were found to have both diabetes mellitus and dyslipidaemia, which was statistically significant. Among hypertensives, $45 \%$ were diabetic compared to $21.6 \%$ among non-hypertensives. Similarly, Bombay executive study(11) showed the prevalence of diabetes amongst hypertensives as $31 \%$ compared to $10.4 \%$ amongst non-hypertensives. Chennai urban population study has reported $25.5 \%$ diabetes amongst hypertensives compared to $8.26 \%$ among normotensives.

A positive family history has a significant role in developing hypertension. Positive family history of hypertension was present in $65.8 \%$ of the hypertensive patients. An epidemiological study conducted by Paul M Anand suggest that $20 \%-60 \%$ of essential hypertension is inherited and remaining is acquired or environmental.[11] In a study of epidemiology of hypertension in rural Haryana under the auspices of the All India Institute of Medical Sciences, the incidence of family history of hypertension was at least 5 times as frequent in hypertensives as in control.[16]

There were a total of 14 subjects whose first-degree relatives had died of CAD at the age below $40 \mathrm{yrs}$. and it was found that all of them were hypertensives; $16.6 \%$ of hypertensives were having first-degree relatives died due to 
CAD before the age of 40 yrs. compared to $3.3 \%$ of normotensives. The Framingham study showed that hypertension causes a two- to four-fold increase in risk of cardiovascular events compared to normotensives of the same age.(17) Bombay executive study showed a prevalence of 20.95\% CHD amongst all hypertensives compared to $4.96 \%$ amongst normotensives. The prevalence amongst all Grade 2 and Grade 3 (JNC XVII) hypertensives was $22.32 \%$.(11)

In our study, we have seen that there is a significant association between BMI and waist-to-hip ratio. Majority of the hypertensives were having high BMI (> 23) and high waist-to-hip ratio which was similar to the study conducted by the Department of Community Medicine in the rural field practice area of a Medical College of Nellore. A linear trend of association was seen with obesity (BMI $>25)$ and waist-hip ratio more than the cut-off value ( $p$ value $<0.005$ ).(14)

Epidemiological observations have identified obesity as a risk factor. The greater the weight gain, the greater the risk of high blood pressure. The Jaipur urban and rural study,(18) Haryana study,(16) the Chennai population study as well as the Bombay executive study(11) have all shown higher weight and BMI among hypertensive group study also showed in a multiple logistic regression analysis that a BMI of $>=25$ $\mathrm{kg} / \mathrm{m} 2$ was associated. A Kerala Study has shown that participants with increased waist circumference $>90 \mathrm{~cm}$ in men and $>85 \mathrm{~cm}$ in women were 1.84 times more likely to be hypertensive compared to those with normal waist circumference. (19)

In our study physical activity, gender, smoking and salt intake were not significantly associated with hypertension. A similar finding was obtained in a cross-sectional study conducted among 369 individuals of 30 yrs. and above attending OPD in rural health training centre under Dept. of Community Medicine, Govt. Medical College, Haldwani during June - August 2013,(20) whereas a majority of the studies showed a positive correlation between physical activity, salt intake and hypertension. Study by Frisoli et al demonstrated a clear relationship between salt intake and the level of blood pressure.(21) Prevalence of hypertension is directly related to the salt intake in a study in rural Kerala; $55.46 \%$ were

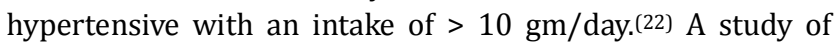
rural population in Central India (Sevagram)(23) found that duration of smoking was significantly related to the prevalence of hypertension. Guedes NG et al found higher prevalence of hypertension in the sedentary group.(24) According to a study conducted in Lucknow in an urban area, hypertensives were less physically active (odds ratio $\mathrm{OR}=$ 4.83), which has significantly contributed to the risk of hypertension.[25]

\section{CONCLUSION}

The prevalence of hypertension is 40\%; 69 persons among known case of hypertensives are having uncontrolled BP. Hypertensives were highest among the individuals in the age group of $50-64$ years (56.6\%). Factors like age (50-64 years), < 10 years of schooling, Below Poverty Line status, alcohol consumption, stress, presence of comorbidities, a family history of hypertension, a history of a first-degree relative having died of coronary artery disease below the age of 40 years, a BMI of $>23$, a waist-to-hip ratio of $>0.9$ (males) and $>0.8$ (females) are significantly associated with hypertension. Awareness programmes and other control programme in the community have to be focused on these important factors.

\section{REFERENCES}

[1] Park K. Park's textbook of preventive and social medicine. 23rd edn. Jabalpur, Banarsidas Bhanot, 2015.

[2] Global Health Observatory Data Repository, http://apps.who.int/gho/data/view.main.2540?lang= en. Last accessed on 22-08-2017.

[3] Reddy KS, Yusuf S. Emerging epidemic of cardiovascular disease in developing countries. Circulation 1998;97(6):596-601.

[4] Singh RB, Beegom R, Mehta AS, et al. Prevalence and risk factors of hypertension and age-specific blood pressure in five cities: a study of Indian women. NKP salve institute of medical sciences, Nagpur, India. Five city study group. Int J Cardiol 1998;63(2):165-73.

[5] Kalavathy MC, Thankappan KR, Sarma PS, et al. Prevalence, awareness, treatment and control of hypertension in an elderly community-based sample in Kerala, India. Natl Med J India 2000;13(1):9-15.

[6] Ministry of Health and Family Welfare, Government of India, Integrated Disease Surveillance Project (IDSP). Non communicable Disease Risk Factors Survey. Kerala 2007-08.

[7] dhs.Kerala.gov.in/index.php/health-policies.

[8] Thakappan KR, Shah B, Mathur P, et al. Risk factor profile for chronic non-communicable diseases: results of a community-based study in Kerala, India. Indian J Med Res 2010;131:53-63.

[9] www.censusindia.gov.in/2011. census/dchb/3213, PART A-Kollam pdf Last accessed on 16-7-2017.

[10] www.who.int/bulletin/archives/1999 77(3)293-4.pdf

[11] Shanthirani CS, Pradeepa R, Deepa R, et al. Prevalence and risk factors of hypertension in a selected South Indian population--the Chennai urban population study. J Assoc Physicians India 2003;51:20-7.

[12] World Health Organization. "A global brief on Hypertension, silent killer, global public health crisis. 2013," 2014 , http://apps.who.int/iris/bitstream/10665/79059/1/ WHO_DCO_WHD_2013.2_eng.pdf. Last accessed on 2109-17.

[13] Kishore J, Gupta N, Kohli C, et al. Prevalence of hypertension and determination of its risk factors in rural Delhi. International Journal of Hypertension 2016;2(1):24-30.

[14] Singh MK, Singamsetty B, Kandati J. An epidemiological study of prevalence of hypertension and its risk factors in a rural community of Nellore, Andhra Pradesh, India. International Journal of Community Medicine Public Health 2016;3(12):340814.

[15] Gasperin D, Netuveli G, Pascoal M, et al. Effect of psychological stress on blood pressure increase: a meta-analysis of cohort studies. Cadernos de Saúde Pública (ENSP. Impresso) 2009;25(4):715-26.

[16] Krishnan A, Shah B, Gupta V, et al. Risk factors of noncommunicable diseases in urban Haryana: a study using the STEPS approach. Indian Heart J 2008;60(1):9-18. 
[17] Dawber TR. The framingham study. The epidemiology of atherosclerotic disease. Cambridge, M.A., Harvard University Press, 1980.

[18] Gupta R, Gupta VP, Bhagat N, et al. Obesity is major determinant of coronary risk factors in India: Jaipur heart watch studies. Indian Heart J 2008;60(1):26-33.

[19] Zachariah G, Harikrishnan S, Krishnan MN, et al. Prevalence of coronary artery disease and coronary risk factors in Kerala, south India: a population surveydesign and methods. Indian Heart J 2013;65(3):243-9.

[20] Bartwal J, Awasthi S, Rawat CMS, et al. Prevalence of hypertension and its risk factors among individuals attending outpatient department of rural health training centre, Haldwani. Indian Journal of Community Health 2014;26(1):76-81.

[21] Frisoli TM, Schmieder RE, Grodzicki T, et al. Salt and hypertension: is salt dietary reduction worth the effort? Am J Med 2012;125(5):433-9.
[22] Sathish T, Kannan S, Sarma PS, et al. Incidence of hypertension and its risk factors in rural Kerala, India: a community based cohort study. Public Health 2012;126(1):25-32.

[23] Joshi R, Taksande B, Kalantri SP, et al. Prevalence of cardiovascular risk factors among rural population of elderly in Wardha district. J Cardiovasc Dis Res 2013;4(2):140-6.

[24] Guedes NG, Lopes MV, Moreira RP, et al. Prevalence of sedentary lifestyle in individuals with high blood pressure. Int J Nurs Terminol Classif 2010;21(2):50-6.

[25] Midha T, Idris M, Saran R, et al. Isolated systolic hypertension and its determinants-a cross sectional study in the adult population of Lucknow district in North India. Indian J Community Med 2010;35(1):8993. 